\title{
PENGARUH OTONOMI, AMBIGUITAS PERAN DAN PROFESIONALISME TERHADAP KINERJA AUDITOR PADA KANTOR AKUNTAN PUBLIK (KAP) DI JAKARTA SELATAN
}

\author{
Oleh: \\ Galih Chandra Kirana, SE., M.Ak \\ Muhammad Ichrom
}

Jurusan Akuntansi Fakultas Ekonomi Universitas Satya Negara Indonesia

\begin{abstract}
ABSTRAK
Isu mengenai profesionalisme marak diperbincangkan menyusul banyaknya skandal akuntansi yang terjadi pada perusahaan-perusahaan besar di dunia seperti Enron Corp, Xerox Corp, WorldCom hingga Walt Disney.Banyak masalah yang terjadi pada berbagai kasus bisnis yang ada saat ini melibatkan profesi akuntan.Sorotan yang diberikan kepada profesi ini disebabkan oleh berbagai faktor diantaranya praktik-praktik profesi yang mengabaikan standar akuntansi bahkan etika, Salah satu faktor yang memoderasi kinerja adalah hubungan kepegawaian yang terdiri dari hubungan kepegawaian antara perusahaan dan karyawan.Para pekerja harus mengendalikan diri dengan pengetahuan dan wawasan tentang etika, moral, dan profesionalisme dalam membangun kekompakkan di antara para rekan kerja secara tulus dan ikhlas.Etika, moral, dan profesionalisme yang dimiliki harus bisa memberikan nilai positif dalam menjaga keutuhan dan kekompakkan organisasi.

Tujuan dari penelitian ini adalah untuk melihat pengaruh Otonomi, Ambiguitas Peran, dan Profesionalisme Terhadap Kinerja Auditor di Kantor Akuntan Publik Jakarta Selatan secara parsial. Populasi dalam penelitian ini adalah Auditor yang bekerja di Kantor Akuntan Publik yang terdaftar di IAPI. Sampel dalam penelitian ini adalah Kantor Akuntan Publik yang terdaftar di IAPI. Teknik sampel yang dilakukan adalah dengan purposive sampling . Data yang digunakan adalah data premier. Alat analisis data yang digunakan adalah SPSS 22.0

Hasil penelitian menunjukan bahwa, Hasil Pekerjaan Auditor yang diukur menggunakan tingkat Ambiguitas Peran tidak memiliki pengaruh yang positif dan signifikan terhadap Kinerja Auditor.Otonomi dan Profesionalisme yang diukur dengan menggunakan hasil pekerjaan yang diselesaikan auditor memiliki pengaruh positif dan signifikan terhadap Kinerja Auditor.
\end{abstract}

Kata Kunci:.Otonomi, Ambiguitas Peran, Profesionalisme 


\section{PENDAHULUAN}

Profesi akuntan publik merupakan sebuah profesi dalam lingkungan bisnis, dinama eksistensinya dari waktu ke waktu semakin diskusi oleh masyarakat bisnis itu sendiri. Semakin pesatnya perkembangan profesi akuntan publik di Indonesia dewasa ini dan meningkatnya pemahaman masyarakat akan profesi akuntan publik mampu membawa perubahan kondisi lingkungan bisnis dan peraturan yang berlaku. Perkembangan tersebut dipicu oleh meningkatnya perekonomian sehingga banyak perusahaan go public yang ikut berperan dalam peningkatkan kebutuhan akan jasa akuntan publik. Semakin mendekati era globalisasi, semua pihak dituntun untuk melakukan persiapan guna menghadapi fenomena dimensional. Salah satunya adalah berlakunya perjanjian perdagangan bebas termasuk bidang jasa.

Tingkat kepercayaan masyarakat akan kualitas audit pada masa sekarang ini mengalami penuruan karena terdapat beberapa kasus yang masih terdapat kecurangan dalam laporan keuangan perusahan dan publik bertanya apakah kantor akuntan publik telah melaksanakan audit dengan baik sesuai dengan standarnya atau belum. Jika kantor audit telah melaksanakan proses audit yang baik maka akan menghasilkan audit yang baik maka akan menghasilkan audit yang berkualitas. Kualitas audit menjadi penting karena dapat berpengaruh pada citra kantor akuntan publik tersebut baik bagi kilen maupun bagi masyarakat. Salah satu kasus yang menimpa Toshiba tahun 2015 merupakan salah satu contoh perusahaan yang melakukan manipulasi laporan keuangan yang melibatkan auditor dalam kecurangan tersebut sehingga menyebabkan laporan keuangan tersebut tidak berkualitas. KAP yang mengaudit laporan keuangan Toshiba yaitu Ernst \& Young Shin Nibon LLC.EY telah bekerja sama melakukan audit untuk Toshiba selama 12 tahun terhitung sejak tahun 2002 hingga 2014 tidak mampu menemukan serta melaporkan kalau perusahaan ini ternyata melakukan kecurangan. Atas kejadian tersebut, regulator keuangan Jepang akan mendenda perusahaan afiliasi Ernst \& Young sebesar 2,1 Miliaryen (US\$17,4 Juta) setelah lembaga tersebut gagal melihat penyimpangan standar akuntansi di Toshiba sertakan menangguhkan Ernst \& Young dalam mengambil Kontrak bisnis baru Selama tiga bulan ( Kompas.com 2016 ).

Adanya fenomena tersebut menggambarkan masih banyak laporan keuangan yang tidak berkualitas. Walaupun menggunakan jasa auditor eksternal akan tetapi auditor tersebut tidak mampu mengungkapkan sehingga menyebabkan menurunya kinerja auditor.

Maka dari latar belakang diatas, penulis tertarik untuk meneliti mengenai kepuasan klien terhadap auditor dengan judul : "Pengaruh Otonomi, Ambiguitas Peran dan Profesionalisme Terhadap Kinerja Auditor Pada Kantor Akuntan Publik (KAP) Di Jakarta Selatan."

\section{Desain Penelitian}

Desain penelitian yang digunakan adalah penelitian kasual (Casual Research) yang merupakan metode penelitian untuk mengidentifikasi hubungan sebab-akibat (Jusuf Soerwadji, 2012). Penelitian kasual digunakan untuk mengetahui pengaruh antara satu atau lebih variable bebas (Independent Variable) terhadap variable terikat (Dependent Variable). 


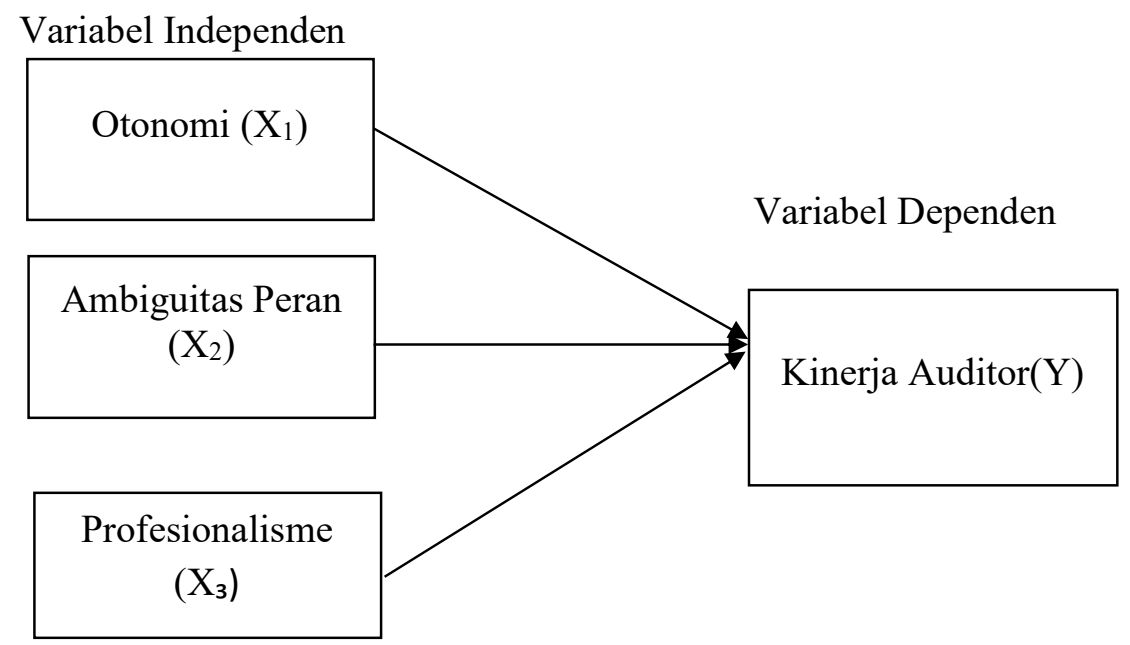

\section{Gambar 2.1}

Desain Penelitian

Berdasarkan kerangka pemikiran yang telah diuraikan diatas, maka dapat diangkat hipotesis penelitian sebagai berikut:

H1: Otonomi berpengaruh signifikan terhadap kinerja auditor.

H2: Ambiguitas Peran berpengaruh signifikan terhadap kinerja auditor.

H3: Profesionalisme berpengaruh signifikan terhadap kinerja auditor.

\section{LANDASAN TEORI}

\section{Teori Auditing}

Audit merupakan suatu ilmu yang digunakan untuk melakukan penilaian terhadap pengendalian intern dimana bertujuan untuk memberikan perlindungan dan pengamanan supaya dapat mendeteksi terjadinya penyelewengandan ketidakwajaran yang dilakukan oleh perusahaan. Proses audit sangat diperlukan suatu perusahaan karena dengan proses tersebut seorang akuntan publik dapat memberikan pernyataan pendapat terhadap kewajaran atau kelayakan laporan keuangan berdasarkan Internasional Standars Auditing yang berlaku umum. Untuk memahami pengertian audit secara baik, berikut ini pengertian audit menurut pendapat beberapa ahli akuntansi.

Menurut Agoes (2012:4) audit adalah suatu permeriksaan yang dilakukan secara kritis dan sistematis, oleh pihak yang independen, terhadap laporan keuangan yang telah disusun oleh manajemen, beserta catatan-catatan pembukuan dan bukti-bukti pendukungnya, dengan tujuan untuk dapat memberikan pendapat mengenai kewajaran laporan keuangan tersebut.

Menurut Mulyadi (2014:9) audit adalah "Suatu proses sistematik untuk memperoleh dan mengevaluasi bukti secara objektif mengenai pernyataan-pernyataan tentang kegiatan dan kejadian ekonomi, dengan tujuan untuk menetapkan tingkat keseuaian antara pernyataanpernyataan tersebut dengan criteria yang telah ditetapkan, serta penyampaian hasil-hasilnya kepada pemakai yang berkepentingan."

\section{Kinerja}

Secara etimologi, kinerja berasal dari kata prestasi kerja (performance).Sebagaimana dikemukakan oleh Mangkunegara (2015), bahwa istilah kinerja berasal dari kata job performance atau actual performance (prestasi kerja atau prestasi sesungguhnya yang dicapai 
seseorang) yaitu hasil kerja secara kualitas dan kuantitas yang dicapai oleh seorang pegawai dalam melaksanakan tugasnya sesuai dengan tanggung jawab yang diberikan kepadanya.

Menurut Ilham Ulum (2012) kinerja auditor merupakan hasil kerja yang dicapai oleh auditor dalam melaksanakan tugasnya sesuai dengan tanggung jawab yang diberikan padanya, dan menjadi salah satu tolak ukur yang digunakan untuk menentukan apakah suatu pekerjaan yang dilakukan akan baik atau sebaliknya. Kinerja auditor menjadi perhatian utama, baik bagi klien ataupun publik, dalam menilai hasil audit yang dilakukan. Kinerja auditor dipengaruhi oleh beberapa faktor beberapa diantaranya adalah adanya konflik peran dalam lingkungan organisasi, adanya ketidakjelasan peran yang dialami auditor serta komitmen organisasi dari setiap auditor dalam melaksanakan tugas audit.

\section{Otonomi}

Menurut Fiscal et al. (2012 : 282) Dalam akuntansi pengertian Otonomi adalah tingkat kebebasan, independensi, dan kebijaksanaan yang dimiliki seseorang dalam merencanakan suatu pekerjaan dan menentukan cara apa yang digunakan untuk melaksanakan pekerjaan tersebut. Otonomi adalah satu dasar dan nilai karakteristik pada pekerjaan professional yang menjadi "sifat" utama yang membedakan profesi itu sendiri. Pandangan lain, otonomi berkaitan dengan kemampuan professional untuk menentukan dan meregulasi aturan yang berhubungan dengan profesi.

Menurut Mulyadi (2002:26) independensi berarti sikap mental yang bebas dari pengaruh, tidak dikendalikan oleh pihak lain dan tidak tergantung pada orang lain. Breaugh dalam Ardhimas (2012:23) mengembangkan tiga skala penilaian aspek otonomi : work method, work schedule, and work criteria. Work method autonomy merupakan kemampuan seseorang memilih cara apa yang digunakan untuk menyelesaikan suatu pekerjaan. Work schedule autonomy merupakan kemampuan seseorang mengatur rangkaian penyelesaian tugas. Work criteria autonomy merupakan kemampuan seseorang menyediakan sumber daya yang dibutuhkan untuk evaluasi.

Penilaian aspek otonomi focus pada keputusan (judgment) professional daripada aspek-aspek teknis seperti penjadwalan kerja dan tugas-tugas administrasi lainnya. Sebagai auditor senior dalam perusahaan, mereka diberikan lebih banyak tanggung jawab dan control pada pekerjaan mereka dan pekerjaan bawahaan.

\section{Ambiguitas Peran}

Menurut teori peran, ambigiutas peran yang dialami dalam waktu yang lama dapat mengikis kepercayaan diri, memupuk ketidakpuasan kerja, dan menghambat kinerja. Ambiguitas peran menurut Kreitner and Kinicki yang diterjemahkan oleh Biro Bahasa Alkemis (2014:16) terjadi ketika anggota tatanan peran gagal menyampaikan kepada penerima peran ekspektasi yang mereka miliki atau informasi yang dibutuhkan untuk melakukan peran tersebut, entah itu karena mereka tidak memiliki informasinya atau karena mereka sengaja menyembunyikannya.

Sedangkan Robbins and Judge yang diterjemahkan oleh Saraswati dan Sirait (2015:306) menyatakan bahwa ambiguitas peran tercipta manakala ekspektasi peran tidak dipahami secara jelas dan karyawan tidak yakin apa yang harus ia lakukan. Ambiguitas peran dirasakan seseorang jika ia tidak memiliki cukup informasi untuk dapat melaksanakan tugasnya, atau tidak mengerti atau merealisasikan harapan-harapan yang berkaitan dengan peran tertentu.

Singkatnya, orang-orang yang mengalami ambiguitas peran yaitu ketika mereka tidak mengetahui apa yang diharapkan dari mereka. Para pendatang baru diperusahaan seringkali mengeluh mengenai deskripsi pekerjaan dan kriteria promosi yang kurang jelek. Menurut 
Krietner and Kinicki yang diterjemahkan oleh Biro Bahasa Alkemis (2014:17), ambiguitas peran yang berkepanjangan bisa menyebabkan hal-hal berikut :

1. Ketidakpuasan akan pekerjaan

2. Mengikis kepercayaan diri

3. Menghambat kinerja pekerjaan

\section{Profesionalisme}

Secara etimologi profesi dari kata profesion yang berarti pekerjaan.Profesional artinya orang yang ahli.Profesionalisme artinya sifat Profesional.Sudarmawan mendefinisikan secara terminologi, profesi dapat diartikan sebagai suatu pekerjaan yang mempersyaratkan pendidikan tinggi bagi pelakunya yang ditekankan pada pekerjaan mental, bukan pekerjaan manual.Kemampuan mental yang dimaksud di sini adalah adanya persyaratan pengetahuan teoritis sebagai instrumen untuk melakukannya perbuatan praktis.

Menurut Arens et al., (2012:105), profesionalisme merupakan tanggung jawab untuk bertindak lebih dari sekedar memenuhi tanggung jawab diri sendiri maupun ketentuan hukum dan peraturan masyarakat.

Profesionalisme bagi akuntan publik adalah perilaku bertanggungjawab terhadap profesi, peraturan, undang-undang, klien dan masyarakat, termasuk para pemakai laporan keuangan.Fakta membuktikan bahwa perilaku professional diperhatikan bagi semua profesi agar mendapat kepercayaan dari masyarakat. Menurut Arens (2012) perilaku profesional bagi akuntan public meliputi :

1. Prinsip-prinsip yang meliputi tanggung jawab, bertindak untuk kepentingan masyarakat, bertindak jujur, integritas, objektivitas, independensi, bekerja cermat, serta mengevaluasi kelayakan lingkup dan sifat jasa.

2. Peraturan perilaku yang harus ditaati oleh profesi akuntan publik.

3. Interprestasi.

4. Kelengkapan etika.

Sebagai profesional, auditor mempunyai kewajiban untuk memenuhi aturan perilaku yang spesifik yang menggambarkan suatu sikap yang ideal. Kewajiban tersebut berupa tanggung jawab yang bersifat fundamental bagi profesi untuk memantapkan jasa yang ditawarkan.Seseorang yang profesional mempunyai tanggung jawab yang lebih besar karena diasumsikan bahwa seseorang profesional memiliki kepintaran, pengetahuan dan pengalaman untuk memahami dampak aktifitas yang dilakukan.

\section{METODOLOGI PENELITIAN}

Metode penelitian menyangkut prosedur dan cara melakukan pengolahan data yang diperlukan untuk menjawab atau memecahkan masalah penelitian termasuk menguji hipotesis. Untuk mengungkap permasalahan dalam penelitian ini, maka peneliti menggunakan metode kausal.Metode kausal merupakan metode yang digunakan untuk mengetahui hubungan antara dua variabel atau lebih.Bentuk metode yang digunakan dalam penelitian ini adalah bentuk kausal (hubungan sebab akibat).

Tabel

Ringkasan Operasional Variabel

\begin{tabular}{|c|c|c|}
\hline Variabel & Indikator & Skala \\
\hline Otonomi $(\mathrm{X} 1)$ & 1. Independensi Pada Pekerjaan. & Ordinal \\
\hline
\end{tabular}




\begin{tabular}{|c|c|c|}
\hline \multirow[t]{3}{*}{ Fiscal et al (2012) } & 2. Wewenang Jabatan. & Ordinal \\
\hline & 3. Partisipasi Penetapan Tujuan. & Ordinal \\
\hline & $\begin{array}{l}\text { 4. Kebebasan Dalam Menerapkan } \\
\text { Audit Judgment. }\end{array}$ & Ordinal \\
\hline \multirow{2}{*}{ Ambiguitas Peran } & 1. Arah dan Tujuan Pekerjaan. & Ordinal \\
\hline & 2. Alokasi Waktu Kerja. & Ordinal \\
\hline Rizzo, House dan & 3. Tanggung Jawab. & Ordinal \\
\hline Litrzman Dalam & 4. Cakupan Pekerjaan. & Ordinal \\
\hline \multirow{6}{*}{$\begin{array}{l}\text { Profesionalisme (X3) } \\
\text { Hiro Tugiman (2013) }\end{array}$} & 1. Pengetahuan dan Pengalaman. & Ordinal \\
\hline & 2. Displin dan Tanggung Jawab. & Ordinal \\
\hline & 3. Pengabdian pada Profesi. & Ordinal \\
\hline & 4. Tanggung Jawab. & Ordinal \\
\hline & 5. Organisasi. & Ordinal \\
\hline & $\begin{array}{l}\text { 6. Merasa Tidak Profesional Jika } \\
\text { Meninggalkan Pekerjaan. }\end{array}$ & Ordinal \\
\hline \multirow{7}{*}{$\begin{array}{l}\text { Kinerja Auditor (Y) } \\
\text { Mangkunegara (2015) }\end{array}$} & 1. Kualitas Pekerjaan. & Ordinal \\
\hline & 2. Usulan Konstruktif. & Ordinal \\
\hline & 3. Hasil Pekerjaan. & Ordinal \\
\hline & 4. Prosedur Audit. & Ordinal \\
\hline & 5. Menilai Kinerja Diri Sendiri. & Ordinal \\
\hline & 6. Apresiasi Pekerjaan. & Ordinal \\
\hline & 7. Hubungan Baik. & Ordinal \\
\hline
\end{tabular}

Sumber : data diolah 2019 


\section{Populasi dan Teknik Penarikan Sampel}

Dalam penelitian ini, populasi yang diambil yaitu auditor yang bekerja di Kantor Akuntan Publik (KAP) yang berada di wilayah Jakarta Selatan sesuai dengan Direktori Kantor Akuntan Publik yang dikeluarkan oleh IAPI pada tahun 2018.

Penentuan KAP yang dijadikan sampel dalam penelitian ini yaitu dengan melakukan konfirmasi kesediaan KAP untuk berpartisipasi dalam pengisian kuesioner, hal ini terkait dengan tingkat kesibukan KAP.Sampel dalam penelitian ini diambil dengan menggunakan metode Purposive Sampling yaitu merupakan teknik pengambilan sampel yang didasarkan atas pertimbangan-pertimbangan tertentu dari peneliti.Pemberian kriteria ini bertujuan agar pernyataan yang terdapat dalam kuesioner penelitian diisi oleh responden yang tepat. Kriteria responden auditor dari KAP yang dijadikan sampel dalam penelitian ini adalah sebagai berikut :

1. Pengalaman melakukan audit minimal 2 tahun.

2. Jenjang pendidikan minimal S1.

\section{HASIL PENELITIAN}

Jumlah kuesioner yang dikirim dan kuesioner yang kembali untuk masing-masing Kantor Akuntan Publik dapat dilihat pada tabel berikut :

\section{Tabel}

Tabel Penyebaran Kuisioner

\begin{tabular}{|c|c|c|c|c|}
\hline No. & $\begin{array}{c}\text { Nama Kantor Akuntan } \\
\text { Publik }\end{array}$ & $\begin{array}{c}\text { Jumlah } \\
\text { kuisioner } \\
\text { disebar }\end{array}$ & $\begin{array}{c}\text { Jumlah } \\
\text { kuisioner yang } \\
\text { tidak kembali }\end{array}$ & $\begin{array}{c}\text { Jumlah } \\
\text { kuisioner yang } \\
\text { kembali } \\
\end{array}$ \\
\hline 1 & $\begin{array}{c}\text { KAP Kanaka, Puradiredja, } \\
\text { Suhartono }\end{array}$ & 10 & - & 10 \\
\hline 2 & $\begin{array}{c}\text { KAP S. Mannan, } \\
\text { Ardiyansyah, \& Rekan }\end{array}$ & 10 & - & 10 \\
\hline 3 & $\begin{array}{l}\text { KAP Junaedi, Chairul, dan } \\
\text { Rekan }\end{array}$ & 10 & - & 10 \\
\hline 4 & $\begin{array}{l}\text { KAP Ishak, Saleh, } \\
\text { Soewondo, \& Rekan }\end{array}$ & 10 & - & 10 \\
\hline 5 & $\begin{array}{l}\text { KAP Drs. Wirawan \& } \\
\text { Rekan }\end{array}$ & 10 & - & 10 \\
\hline 6 & KAP Rio Simorangkir & 10 & 5 & 5 \\
\hline 7 & KAP Susilo Kristiaji & 10 & 4 & 6 \\
\hline 8 & $\begin{array}{l}\text { KAP Drs. A. Salam Rauf \& } \\
\text { Rekan }\end{array}$ & 10 & - & 10 \\
\hline 9 & $\begin{array}{c}\text { KAP Gatot Permadi, Azwir, } \\
\text { Abimail }\end{array}$ & 10 & 3 & 7 \\
\hline 10 & $\begin{array}{l}\text { KAP Slamet Riyanto, } \\
\text { Aryanto \& Rekan }\end{array}$ & 10 & 3 & 7 \\
\hline & Total & 100 & 15 & 85 \\
\hline & Prentase & $100 \%$ & $15 \%$ & $85 \%$ \\
\hline
\end{tabular}

Sumber: Auditor KAP Wilayah Jakarta Selatan, data diolah 2019 


\section{Uji Reliabilitas}

Nilai Cronbach's Alpha yang biasanya digunakan yaitu: lebih besar dari 0,7 atau > 0,7. Semakin besar nilai Cronbach's Alpha, maka semakin baik pula pengukuran variabel tersebut.

\section{Tabel}

\section{Uji Reliabilitas}

\begin{tabular}{|c|c|c|c|c|}
\hline No. & Variabel & $\begin{array}{c}\text { Cronbach's } \\
\text { Alpha }\end{array}$ & Item Indikator & Kesimpulan \\
\hline 1 & Otonomi & 0,856 & 4 & Reliable \\
\hline 2 & $\begin{array}{c}\text { Ambiguitas } \\
\text { Peran }\end{array}$ & 0,975 & 4 & Reliable \\
\hline 3 & Profesionalisme & 0,861 & 7 & Reliable \\
\hline 4 & Kinerja Auditor & 0,844 & 7 & Reliable \\
\hline
\end{tabular}

Sumber : Output Spss Versi 22

Berdasarkan hasil uji reliabilitas di atas dapat disimpulkan bahwa pernyataan dalam kuisioner ini reliable karena mempunyai nilai Cronbach's Alpha lebih besar dari 0,7 artinya Otonomi, Ambiguitas Peran, Profesionalisme, dan Kinerja Auditor bersifat reliabel atau dapat dipercaya.

\section{Uji Normalitas} berikut :

Hasil uji normalitas dengan menggunakan Uji Kolmogorof Smirnov adalah sebagai

Tabel

\section{Uji Normalitas}

\begin{tabular}{|ll|r|}
\hline \multicolumn{2}{|c|}{ One-Sample Kolmogorov-Smirnov Test } \\
\hline $\mathrm{N}$ & $\begin{array}{c}\text { Unstandardized } \\
\text { Residual }\end{array}$ \\
\hline Normal Parameters $\mathrm{a}, \mathrm{b}$ & Mean & 85 \\
& Std. Deviation &, 0000000 \\
Most Extreme Differences & Absolute &, 21728474 \\
& Positive &, 073 \\
& Negative &, 073 \\
Test Statistic & &,- 046 \\
Asymp. Sig. (2-tailed) & &, 073 \\
\hline
\end{tabular}

a. Test distribution is Normal.

b. Calculated from data.

Sumber : Output Spss Versi 22

Berdasarkan hasil uji normalitas dengan One Sample Kolmogorov dapat diketahui bahwa data dalam penelitian terdistribusi normal. Hal ini dapat dilihat dari Asymp Sig (2tailed) nilai Sig $=0,200>\alpha=0,05$ berarti dapat disimpulkan bahwa data tersebut berdistribusi normal dan populasi berdistribusi normal. 


\section{Uji Multikolinieritas}

Uji Multikoliniearitas bertujuan untuk menguji apakah model regresi ditemukan adanya korelasi antar variabel bebas (independent).

Tabel

\section{Uji Multikoliniearitas}

\begin{tabular}{|ll|r|c|}
\hline \multirow{2}{*}{ Model } & \multicolumn{2}{|c|}{ Collinearity Statistics } \\
\cline { 3 - 4 } & & Tolerance & \multicolumn{1}{c|}{ VIF } \\
\hline 1 & (Constant) & & \\
& OTONOMI &, 463 & 2,158 \\
& AMBIGUITAS PERAN &, 995 & 1,006 \\
& PROFESIONALISME &, 462 & 2,163 \\
\hline
\end{tabular}

Sumber Output SPSS 22

Berdasarkan hasil tabel di atas, dapat dilihat bahwa masing- masing variable independen yang digunakan dalam penelitian memiliki nilai VIF $<10$ dan Tolerance $>0,10$. Yaitu dengan nilai dari variable Otonomi mempunyai VIF 2,158 dan Tolerance 0,463, nilai variable Ambiguitas Peran mempunyai VIF 1,006 dan Tolerance 0,995, dan nilai dari variable Profesionalisme mempunyai VIF 2,163 dan Tolerance 0,462. Hal ini menandakan bahwa variable-variable yang digunakan tidak terjadi masalah multikolinearitas.

\section{Uji Heterokedastisitas}

Untuk menguji hal ini digunakan Scatterplot, dimana sumbu $\mathrm{X}$ adalah nilai-nilai prediksi, Selain itu uji heterokedastisitas dilakukan dengan uji glejser, dengan melihat nilai Sig lebih besar dari 0,05 maka tidak terjadi heterokedastisitas, maka berikut hasil ujinya :

Tabel 4.14

\section{Uji Heterokedastisitas}

\begin{tabular}{|ll|r|r|}
\hline Model & & $\mathrm{T}$ & \multicolumn{1}{c|}{ Sig. } \\
\hline 1 & (Constant) & 3,982 &, 000 \\
& Otonomi & $-1,317$ &, 191 \\
& Ambiguitas Peran & $-1,843$ &, 069 \\
& Profesionalisme &, 499 &, 619 \\
\hline
\end{tabular}

a. Dependent Variable: Abs_RES

Sumber : Output Spss Versi 22

Dari output di atas dapat dapat diketahui bahwa nilai sig variabel Otonomi, Ambiguitas Peran dan Profesionalisme diatas 0,05, Jadi dapat disimpulkan bahwa tidak terjadi heterokedastisitas dalam model regresi atau uji glejser 


\section{Uji Auto Korelasi}

Uji autokorelasi bertujuan menguji apakah dalam model regresi linear ada korelasi antara kesalahan pengganggu pada periode $\mathrm{t}$ dengan kesalahan pengganggu pada periode $\mathrm{t}-1$ (sebelumnya). Model regresi yang baik adalah regresi yang bebas dari autokorelasi. Metode pengujian yang sering digunakan adalah dengan uji Durbin-Watson (Uji DW).

Tabel

Uji Auto Korelasi

\begin{tabular}{|l|r|r|r|r|r|}
\hline Model & \multicolumn{1}{|c|}{$\mathrm{R}$} & $\mathrm{R}$ Square & \multicolumn{1}{c|}{$\begin{array}{c}\text { Adjusted R } \\
\text { Square }\end{array}$} & $\begin{array}{l}\text { Std. Error of the } \\
\text { Estimate }\end{array}$ & Durbin-Watson \\
\hline 1 &, $723^{\mathrm{a}}$ &, 523 &, 505 & 3,27632 & 1,827 \\
\hline
\end{tabular}

a. Predictors: (Constant), PROFESIONALISME, AMBIGUITAS PERAN, OTONOMI

b. Dependent Variable: KINERJA AUDITOR

Sumber : Output Spss Versi 22

Berdasarkan hasil tabel diatas dengan uji Durbin Watson menunjukkan nilai sebesar 1,827 yang artinya bahwa $\mathrm{dU}<\mathrm{d}<4$-dU maka diindikasikan tidak ada autokorelasi.

\section{Analisis Regresi Linier Berganda}

Dalam Pengolahan data dengan menggunakan metode regresi linear berganda, dilakukan beberapa tahapan untuk mencari hubungan variable independen dan variable dependen, yaitu dengan cara menganalisis Otonomi (X1), Ambiguitas Peran (X2), dan Profesionalisme (X3), terhadap Kinerja Auditor (Y).

\section{Tabel}

\section{Uji Analisis Regresi Linier Berganda}

\begin{tabular}{|c|c|c|c|c|c|c|}
\hline \multirow{2}{*}{\multicolumn{2}{|c|}{ Model }} & \multicolumn{2}{|c|}{ Unstandardized Coefficients } & \multirow{2}{*}{$\begin{array}{c}\text { Standardized } \\
\text { Coefficients } \\
\text { Beta }\end{array}$} & \multirow[b]{2}{*}{$\mathrm{t}$} & \multirow[b]{2}{*}{ Sig. } \\
\hline & & B & Std. Error & & & \\
\hline \multirow[t]{4}{*}{1} & (Constant) & 6,180 & 1,883 & & 3,282 & ,002 \\
\hline & Otonomi & ,351 &, 167 & ,237 & 2,098 & 039 \\
\hline & Ambiguitas Peran &,- 067 & ,105 &,- 049 &,- 640 &, 524 \\
\hline & Profesionalisme &, 515 & 109 &, 534 & 4,730 &, 000 \\
\hline
\end{tabular}

a. Dependent Variable: Kinerja Auditor

Sumber : Output Spss Versi 22

Berdasarkan tabel 4.18 maka diperoleh bentuk persamaan model regresi linear berganda sebagai berikut:

$$
\begin{array}{r}
Y=\alpha+\beta_{1} X_{1}+\beta_{2} X_{2}+\beta_{3} X_{3}+€ \\
Y=\mathbf{6 , 1 8 0}+\mathbf{0 , 3 5 1} \mathbf{X}_{\mathbf{1}}-\mathbf{0 , 0 6 7} \mathbf{X}_{\mathbf{2}}+\mathbf{0 , 5 1 5} \mathbf{X}_{\mathbf{3}}
\end{array}
$$

Model tersebut dapat di interpretasikan sebagai berikut :

1. Nilai a (konstanta) pada hasil pengujian di atas adalah sebesar 6,180 yang berarti bahwa jika variabel independen (Otonomi, Ambiguitas Peran, dan Profesionalisme) konstan, maka Kinerja Auditor akan mengalami kenaikan sebesar 6,180. Nilai 
konstanta sebesar 6,180 menunujukkan nilai murni dari variabel Kinerja Auditor (dependen) tanpa di pengaruhi variabel independen.

2. Koefisien regresi Otonomi adalah sebesar 0,351 dimana angka ini menunjukkan bahwa setiap peningkatan variabel Otonomi sebesar satu satuan, maka akan meningkatkan Kinerja Auditor sebesar 0,351. Koefisien bernilai positif artinya terdapat hubungan positif antara Otonomi. Semakin meningkat Otonomi maka akan meningkatkan Kinerja Auditor.

3. Koefisien regresi Ambiguitas Peran adalah sebesar -0,067 dimana angka ini menunjukkan bahwa setiap penurunan variabel Ambiguitas Peran sebesar satu satuan, maka akan menurunkan Kinerja Auditor sebesar -0,067. Koefisien bernilai negatif artinya terdapat hubungan negatif Ambiguitas Peran. Semakin menurun Ambiguitas Peran, maka akan meningkatkan Kinerja Auditor.

4. Koefisien regresi Profesionalisme adalah sebesar 0,515 dimana angka ini menunjukkan bahwa setiap peningkatan variabel Profesionalisme sebesar satu satuan, maka akan meningkatkan Kinerja Auditor sebesar 0,515. Koefisien bernilai positif artinya terdapat hubungan positif antara Profesionalisme. Semakin meningkat Profesionalisme, maka akan meningkatkan Kinerja Auditor.

\section{Uji Parsial ( Uji t )}

Uji t digunakan untuk mengetahui apakah dalam model regresi variabel bebas (independent variable) secara parsial (individual) berpengaruh terhadap variabel terikat (dependen variable).

Tabel

\section{Hasil Uji Signifikansi Parsial (Uji t)}

\begin{tabular}{|c|c|c|c|c|c|c|}
\hline \multirow{2}{*}{\multicolumn{2}{|c|}{ Model }} & \multicolumn{2}{|c|}{ Unstandardized Coefficients } & \multirow{2}{*}{$\begin{array}{c}\begin{array}{c}\text { Standardized } \\
\text { Coefficients }\end{array} \\
\text { Beta } \\
\end{array}$} & \multirow[b]{2}{*}{$\mathrm{t}$} & \multirow[b]{2}{*}{ Sig. } \\
\hline & & B & Std. Error & & & \\
\hline \multirow[t]{4}{*}{1} & (Constant) & 6,180 & 1,883 & & 3,282 & ,002 \\
\hline & Otonomi &, 351 & , 167 & ,237 & 2,098 & 039 \\
\hline & Ambiguitas Peran &,- 067 & , 105 &,- 049 &,- 640 &, 524 \\
\hline & Profesionalisme &, 515 & 109 & ,534 & 4,730 &, 000 \\
\hline
\end{tabular}

a. Dependent Variable: Kinerja Auditor

Sumber : Output Spss Versi 22

1. Hipotesis yang pertama adalah Otonomi, dimana variabel ini untuk melihat pengaruh antara variabel independen (Otonomi) dengan variabel dependen (Kinerja Auditor), dengan hipotesis $\left(H_{0}\right)$ dan hipotesa alternatif $\left(H_{1}\right)$ sebagai berikut :

$H_{0}$ : Otonomi tidak berpengaruh terhadap Kinerja Auditor.

$H_{1}$ : Otonomi berpengaruh terhadap Kinerja Auditor.

Berdasarkan tabel 4.17 diatas terlihat bahwa $t_{\text {hitung }}>t_{\text {tabel }}$ yaitu 2,098 $>$ 1,990 sedangkan nilai signifikan yang dihasilkan lebih kecil dari alpha $(\alpha)$, yakni $0,039<0,05$. Hal ini berarti menunjukkan bahwa keputusan yang diambil adalah menolak $\mathrm{H} 0$ dan menerima $\mathrm{H} 1$, berarti secara parsial Otonomi berpengaruh secara signifikan terhadap Kinerja Auditor. 
2. Hipotesis yang kedua adalah Ambiguitas Peran, dimana variabel ini untuk melihat pengaruh antara variabel independen (Ambiguitas Peran) dengan variabel dependen (Kinerja Auditor), dengan hipotesis $\left(H_{0}\right)$ dan hipotesa alternatif $\left(H_{1}\right)$ sebagai berikut :

$H_{0}$ : Ambiguitas Peran tidak berpengaruh terhadap Kinerja Auditor.

$H_{1}$ : Ambiguitas Peran berpengaruh terhadap Kinerja Auditor.

Berdasarkan tabel 4.17 diatas terlihat bahwa $t_{\text {hitung }}>t_{\text {tabel }}$ yaitu $-0,640$ $<1,990$ sedangkan nilai signifikan yang dihasilkan lebih besar dari alpha $(\alpha)$, yakni 0,524 >0,05. Hal ini berarti menunjukkan bahwa keputusan yang diambil adalah menerima $\mathrm{H} 0$ dan menolak H1, berarti secara parsial Ambiguitas Peran tidak berpengaruh terhadap Kinerja Auditor.

3. Hipotesis yang ketiga adalah Profesionalisme, dimana variabel ini untuk melihat pengaruh antara variabel independen (Profesionalisme) dengan variabel dependen (Kinerja Auditor),dengan hipotesis $\left(H_{0}\right)$ dan hipotesa alternatif $\left(H_{1}\right)$ sebagai berikut:

$H_{0}$ : Profesionalisme tidak berpengaruh terhadap Kinerja Audit

$H_{1}$ : Profesionalisme berpengaruh terhadap Kinerja Auditor Berdasarkan tabel 4.17 diatas terlihat bahwa $t_{\text {hitung }}>t_{\text {tabel }}$ yaitu $4,730>1,990$ sedangkan nilai signifikan yang dihasilkan lebih kecil dari alpha $(\alpha)$, yakni $0,000<0,05$. Hal ini berarti menunjukkan bahwa keputusan yang diambil adalah menolak H0 dan menerima H1, berarti secara parsial Profesionalisme berpengaruh secara signifikan terhadap Kinerja Auditor.

\section{PENUTUP}

\section{Kesimpulan}

Penelitian ini bertujuan untuk mengetahui pengaruh variabel Otonmi, Ambiguitas Peran, Dan Profesionalisme Terhadap Kinerja Auditor Di Kantor Akuntan Publik (KAP) Jakarta Selatan. Berdasarkan hasil penelitian seperti yang telah diuraikan pada bab sebelumnya, dapat ditarik kesimpulan secara parsial yaitu :

1. Otonomi berpengaruh signifikan terhadap Kinerja Auditor di Kantor Akuntan Publik Jakarta Selatan. Dapat dilihat dari t hitung lebih besar jika dibandingkan t table $(2,098$ $>1,990)$ serta nilai signifikansi Otonomi terhadap Kinerja Auditor lebih besar dari nilai signifikansi $(0,39<0,05)$ sehingga menolak $\mathrm{H} 1$.

2. Ambiguitas Peran tidak berpengaruh secara negatif terhadap Kinerja Auditor di Kantor Akuntan Publik Jakarta Selatan. Dapat dilihat dari t hitung lebih kecil jika dibandingkan $\mathrm{t}$ table $(-0,640<1,990)$ serta nilai signifikansi Ambiguitas Peran terhadap Kinerja Auditor lebih besar dari nilai signifikansi $(0,524>0,05)$ sehingga menerima $\mathrm{H} 1$.

3. Profesionalisme berpengaruh signifikan terhadap Kinerja Auditor di Kantor Akuntan Publik Jakarta Selatan. Dapat dilihat dari t hitung lebih besar jika dibandingkan t table $(4,750>1,990)$ serta nilai signifikansi Profesionalisme terhadap Kinerja Auditor lebih kecil dari nilai signifikansi $(0,000<0,05)$ sehingga menerima $\mathrm{H} 1$.

\section{Saran}

Berdasarkan penjelasan hasil penelitian dan pembahasan serta simpulan dalam penelitian ini maka saran dalam penelitian ini adalah:

1. Penelitian ini dapat dikembangkan lebih luas untuk Kantor Akuntan Publik atau Jasa Akuntansi yang terdaftar di IAPI maupun OJK yang bukan hanya berada di wilayah Jakarta Selatan. 
2. Untuk peneliti selanjutnya dapat menambah pengujian faktor-faktor yang mempengaruhi Kinerja Auditor selain Otonomi, Ambiguitas Peran dan Profesionalisme misalnya Independensi, dan Etika Profesi.

3. Penelitian berikutnya diharapkan dapat menambah jumlah sampel dan mewakili masing-masing sub sektor sehingga hasilnya mampu menggambarkan secara menyeluruh keadaan Kantor Akuntan Publik di Indonesia. Selain itu, peneliti juga dapat memperpanjang periode pengamatan yang akan diteliti.

\section{DAFTAR PUSTAKA}

Buku :

Ghozali. 2012 Aplikasi Analisis Multivariate IBM SPSS 22. Semarang: Universitas Diponegoro.

Hanna, E., \& Firnanti, F. (2013). Faktor-faktor yang Mempengaruhi Kinerja Auditor. Jurnal Bisnis dan Akuntansi, 13-28..

Herry. 2009. Teori Akuntansi Edisi I. Jakarta.

Luthans, Fred, 2005. Perilaku Organisasi dan Atribusi, Edisi Sepuluh, Diterjemahkan oleh : VivinAndhika Yuwono; Shekar Purwanti; Th.Arie Prabawati; dan Winong Rosari.Penerbit Andi, Yogyakarta.

Mangkunegara AP, 2015, Perencanaan dan Pengembangan Sumber DayaManusia, Rfika Aditama, Bandung.

Mangkunegara, 2005, Evaluasi Kinerja Sumber Daya Manusia, Refika Aditama. Jakarta.

Mulyadi. (2014). Auditting. Jakarta: Salemba Empat.

Pratina, Angga. (2011)."Role Ambiguity dan Role Conflict sebagai antaseden dari Job Insecurity pada Contingen Worker". Yogyakarta: STIM YKPN

Ridwan, \& Engkos, K. A. (2007). Cara Menggunakan dan Memaknai Analisis Jalur (Path Analysis). Cetakan Pertama. Bandung: Alphabeta.

Robbins, S. P., \& Judge, T. A. (2015). Perilaku Organisasi (Organizational Behavior). Jakarta: Salemba Empat.

Santoso, Singgih. 2011. SPSS Statistic Parametric . Jakarta: PT Alex Media Computindo Gramedia.

Setiawan, I. A dan Ghozali, I. 2006. Akuntansi Keperilakuan (Konsep dan Kajian Empiris Perilaku Akuntan, Universitas Diponegoro, Semarang, BP UNIP.

Soewadji, J. (2012). Pengantar Metodologi Penelitian. Jakarta: Mitra Wacana Media.

Sugiyono. 2015. Metode Penelitian Kuantitatif Kualitatif dan R\&D. Bandung: Alfabeta. 
Tugiman, Hiro. (2013). Standar Profesional Audit Internal. Kansius : 2011.

Jurnal :

Aulia. I. A. (2015). Pengaruh Pengalaman, Otonomi, Pengendalian Perilaku, dan Pengendalian Personal terhadap Kinerja Auditor Internal pada Perbankan Kantor Wilayah X Bank Mandiri Makassar. Skripsi. Universitas Hasanuddin Makasar.

Hutami, Gartiria. (2011). "Pengaruh Konflik Peran dan Ambiguitas Peran terhadap Komitmen Independensi Auditor Internal Pemerintahan Daerah". Semarang. Universitas Diponegoro.

Kharismawan Sindudisastra, Lusius (2014). "Pengaruh Konflik Peran dan Ambiguitas PEran Terhadap Komitmen Independensi Auditor Internal. Yogyakarta. Universitas Atma Jaya Yogyakarta

Pratina, Angga. (2011)."Role Ambiguity dan Role Conflict sebagai antaseden dari Job Insecurity pada Contingen Worker". Yogyakarta: STIM YKPN

Ramadhanty. R. W. (2013)."Pengaruh Pengalaman, Otonomi, Profesionalisme, dan Ambiguitas Peran Terhadap Kinerja Auditor Pada KAP di DIY". Skripsi. Universitas Negeri Yogyakarta.

Syauffa Pratiwi Hutasuhut, Reskino (2016). "Pengaruh Budaya Organisasi, Pelaksanaan Tanggung Jawab, Otonomi Kerja, dan Ambiguitas Peran terhadap Kinerja Auditor. Akuntabilitas : Jurnal Ilmu Akuntansi.

Wisesa, A. L. (2012). "Pengaruh Exercised Responsibility, Pengalaman, Otonomi, dan Ambiguitas Peran terhadap Kinerja Auditor Disemarang". Skripsi. Universitas Diponegoro.

Website :

$\underline{\text { www.googlescholar.com }}$

www.iapi.or.id 